\title{
Modern Sovereign Money-Part I: The Moral Hazard of Fractional Reserve Banking
}

\author{
Christian Etzrodt \\ International College of Liberal Arts, Yamanashi Gakuin University, Kofu, Japan \\ Email: etzrodtc@hotmail.com
}

How to cite this paper: Etzrodt, C. (2018) Modern Sovereign Money-Part I: The Moral Hazard of Fractional Reserve Banking. Open Journal of Social Sciences, 6, 101-115.

https://doi.org/10.4236/jss.2018.69007

Received: August 8, 2018

Accepted: September 2, 2018

Published: September 5, 2018

Copyright (c) 2018 by author and Scientific Research Publishing Inc. This work is licensed under the Creative Commons Attribution International License (CC BY 4.0).

http://creativecommons.org/licenses/by/4.0/

\begin{abstract}
The aim of this paper is to show that problems in financial markets are not the result of unethical behaviour of specific individuals, but instead are caused by a fundamental conflict of interests between the private banks and society. By inflating bubbles through fractional reserve banking and securitization the private banks can increase profits but also increase the risks for the society at large. I will discuss why the most common proposals for reducing the risk for society are very likely not solving the problem, because they do not resolve the fundamental conflict of interest.
\end{abstract}

\section{Keywords}

Financial Crisis, Fractional Reserve Banking, Money Creation

\section{Introduction}

The Global Financial Crisis, also known colloquially as The Great Recession, has led many people to question the current financial system. The bursting of the U.S. sub-prime housing bubble in 2007 that led to the collapse of Lehman Brothers and AIG and the beginning of the global recession in 2008 has severely destroyed our trust in the efficiency of the current state of capitalism. But this economic crisis is also an opportunity to learn from the mistakes of the past and to design an economic system that much better serves the interest of the people.

This analysis aims to show that the fundamental conflict of interest which exists between private banks (non-government owned banks) and the society at large is the cause of this catastrophic development. Therefore, most of the discussed solutions for this recession are not going to work. It is not only a problem of a lack of regulation, but a basic flaw in the design of the banking sector.

In order to develop this argument I will first discuss the build up of the financial crisis. Thereafter, I will address the failure of more common proposals to 
combat the main underlying problem. In the second part of this series I will outline more radical alternative proposals for designing a financial system as for example the Chicago Plan, the Positive Money approach, and the Modern Money Theory. I am focussing here on the role of the private banks. Of course, fraudulent practices of home mortgage lenders, politicians, who wanted to increase home ownership of the poor, a low-interest policy of the Federal Reserve, and global trade imbalances have contributed to the collapse too. But those factors were specific to this particular crisis. They are not the real cause of the problem in general.

\section{Conflict of Interest between the Private Banks and the Whole Society}

\subsection{Money Creation by Private Banks}

It might be a surprising fact, but private banks create money. Keep in mind that money is not only cash in the form of coins and bills supplied by the central banks, but also the money in the bank accounts. Two different models exist that describe how private banks create money. The dominant model is the money multiplier theory, which can be found in most textbooks ([1]: pp. 467-469; [2]: pp. 393-405; [3]: pp. 88-90). The following example (see also Figure 1) will explain the money creation process in this model. Let's assume we have in an economy only $\$ 1000$ in cash in the hands of various people $A_{i}$. Let's furthermore assume that these people do not need their money and lend it to the private bank as a deposit. The private bank can now give a loan of $\$ 900$ (the $\$ 900$ of the deposits of $A_{i}$ minus a $10 \%$-reserve of $\$ 90$ ) to company $B$ to increase production. Company $B$ hires more workers $B_{i}$ with this money who give their money as deposits to the private bank. The private bank uses a fraction of this deposit again

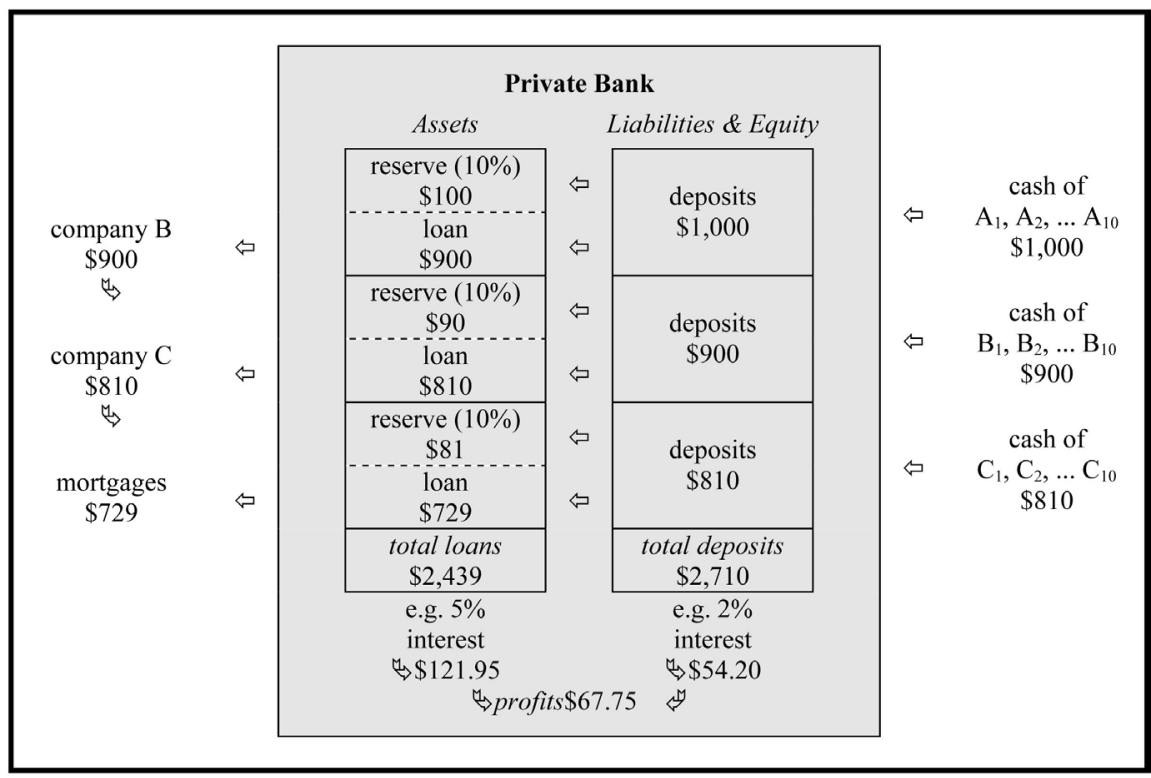

Figure 1. Fractional Reserve Banking. 
for a new loan of $\$ 810$ (the $\$ 810$ minus the $10 \%$-reserve) to company $\mathrm{C}$, which again gives the money to their workers $\mathrm{C}_{\mathrm{i}}$, who lend their money again to the private bank. And the bank uses $90 \%$ of the deposits again as loans for mortgages. Let's stop here, although we could go on. Altogether a reserve requirement of $10 \%$ as in this example implies that the base money of $\$ 1000$ could be multiplied by 10 , if the private bank would continue this process to its end. However, the relevant point is that in the whole process there was only $\$ 1000$ in coins and bills available in the entire economy. But at the end of the process there was $\$ 729$ floating around in the economy plus the $\$ 2710$ - the total amount of deposits-in the private bank. This adds up to $\$ 3439$. In other words, the private bank has created $\$ 2439$ out of thin air through the process of fractional reserve banking. For this $\$ 2439$ no coins or bills exist. This money exists only in the books of the private bank ([4]: p. 182).

The key aspects of this money multiplier theory are that private banks are passive, because they have to wait until customers make deposits before they can make loans, and that the private banks' ability to create money is controlled by the central bank through the reserve requirements ([5]: p. 76; [6]: pp. 20, 33f).

The second model that explains the creation of money by private banks is the post Keynesian endogenous money theory. Endogenous money theorists claim a reverse causality between deposits and loans ([7]: p. 63). Under this, private banks don't need to wait for customers to deposit money. They create loans whenever they want. This decision is independent of the question whether money is available in reserve or not, because private banks are always able to get money later, directly from the market or the central bank, which needs to supply the required money to the private banks in order to keep the interest rate stable ([5]: p. 78; [8]: p. 10; [9]: p. 405; [10]: p. 1425). The key aspects of this model are that private banks are actively creating loans, and that the central bank has very limited means to control the private banks' ability to create money. Therefore, private banks and not the central bank determine the money supply in the economy ([5]: p. 80). It is interesting that central bankers like Mervyn King, Governor of the Bank of England, VítorConstâncio, Vice-President of the European Central Bank, and PitiDistayat, Bank for International Settlements, reject the money multiplier theory, admitting to the accuracy of the endogenous money theory ([5], pp. 78-79). Both the Federal Reserve Bank of Chicago and the German central bank confirm this too ([11]: p. 5f; [12]: p. 92). Furthermore, a recent publication of the Bank of England leaves no doubt about which model is correct and states that the money multiplier theory is a popular misconception ([13]: p. 14).

But maybe it would be more accurate to say that central banks do not want to control the money supply. As James Rowbotham ([14]: p. 107) has pointed out it is indeed remarkable to what "lengths governments will go to not to create money", but instead transferring to private banks "the ultimate in financial power".

Independent of the question of which model describes the money creation 
process of private banks correctly, it is obvious why private banks have a strong interest in making loans during stable periods, since they can increase their profits through the difference of the interest rate for deposits and loans (see Figure 1; of course, if a private bank creates loans without using deposits of customers, then the profits are even higher). "This difference is privately appropriated by the small group that owns the privilege to privately create money [...] as a result of intense rent-seeking behavior" ([15]: p. 13). But what is in the best interest of the private bank is not necessarily in the best interest of the bank's customers. The first problem is that the depositors can never get all their money back in the same moment, because the banks have not enough reserves in cash for the deposits (in the example, $\$ 271$ for $\$ 2710$ ). They can only get the other $90 \%$ of their deposits back, if the people who borrowed the money from the bank do not default (cf. [16]: p. 105). It is therefore in the interest of the depositors to require private banks to keep a large amount deposited on reserve, because the higher the reserves the lower the risks for each depositor in the case of default (e.g. bank runs). This however is a problem for the private banks, because higher reserves also imply lower profits ([17]: p. 377), because the same amount of money can be less often leveraged. Private banks have therefore a strong incentive to increase the risks by reducing the reserves. It should be mentioned at this point that bank runs are not only bad for the depositors but also for the whole economy. Firstly, the failure of private banks can easily lead to a long lasting depression. And secondly, the depositors can be usually only saved with taxpayers' money ([18]: p. 10).

\subsection{Private Bank Regulations and Evasive Strategies}

The strong negative impact of bank failure on the rest of the economy is the reason why private banks are regulated ([19]: p. 12). In 1988 the Bank of International Settlements (BIS) in Basel, Switzerland established the universal standard for private banks. This standard regulates the minimum requirements of the bank's capital and loan-loss reserves-money set aside for the case that loans default ([5]: p. 95; [20]). However, those regulations have loopholes, because the requirements on one's own capital and reserves depend on the risks involved. Only some assets such as commercial loans have a full risk weight of $100 \%$. Mortgages on the other hand have a reduced risk weight of $50 \%$, because they are secured by the value of the property. And finally government securities have a risk weight of $0 \%$ or no risk at all, because it is assumed that states never default (this assumption is of course wrong, since sovereign states can default). The amount of money that private banks are required to set aside for their assets can be reduced by accumulating more safe assets ([21]: pp. 21-23). The higher the risks are, the higher the requirements for reserves and the lower the profits [20]. Obviously, private banks have a strong interest in reducing the risks of their assets. And the solution to this problem of the private banks is securitization. Indeed most of the financial innovations were "specifically designed to conceal 
risk, obfuscate investors and reduce transparency" [22].

Private banks could evade the regulations, if they somehow could argue that their risky commercial loans or mortgages are as safe as government securities. In this case they would need fewer reserves and could create more money, which would increase their profits. In order to achieve this, the banks invented credit default swaps (CDS). A CDS is basically an insurance for the risk that a borrower defaults. With this insurance, the private banks argued, the risk disappears, and therefore commercial loans should be treated as equivalent to government securities (cf. [19]: p. 8, 84; [20]; [23]: p. 49; [24]: p. 61). The American regulators quickly accepted this argumentation and by 1996 the Federal Reserve declared that private banks are "allowed to reduce capital reserves by using credit derivatives" [20].

But although this was a good solution for the private banks, it was not the best solution for society. Remember that the regulations were introduced in order to limit the amount of loans private banks can create without producing too much risk for the whole economy. The more loans a private bank creates and the smaller reserve it has, the higher the risk of bank runs in the case that borrowers default. The problem is that CDS circumvent the regulations that limit the risks for the entire economy. The problem gets even worse, because CDS are traded on unregulated over-the-counter (OTC) markets. In contrast to other forms of insurances CDS can be sold without the requirement to keep reserves in the case that the insurance has to be paid out ([23]: p. 50; [25]: p. 367).

Obviously, an insurance does not reduce the risk for a private bank in case that a borrower of a loan defaults, if the firm that issued the insurance is not able to cover for the loss of the private bank. But why did the Federal Reserve accept this new financial tool, if it was designed to evade regulations? The Financial Crisis Inquiry Commission ([23]: p. xviii) concluded that this was largely the result of deregulation (cf. [19]: p. 15; [26]: p. 3). In 1994 the American Congress deregulated the banking sector, which allowed bank holding companies to "acquire banks in every state, and removed most restrictions on opening branches in more than one state" ([23]: p. 52). In 1999 most of the remaining Glass-Steagall restrictions were abolished ([23]: p. 55). And in 2000 President Clinton legalized OTC derivatives and eliminated oversight of OTC markets ([23], p. xxiv, 48). Mervyn King ([16]: p. 33), Governor of the Bank of England from 2003 to 2013, accused the politicians of putting pressure on the regulators "not to impede the expansion of the sector." The political shift towards deregulation of the financial markets in the US and the UK was again in large part made possible by the private banks through lobbying ([19]: p. 9; [23]: p. xviii; [27]: p. 3; [28]: p. 147; cf. [29]: p. 162).

Another possible reason for the quick legalization of CDS is the close connection between "key policy makers-the Treasury Department, the Federal Reserve Board, and the Federal Reserve Bank of New York" ([23]: p. xxi)—in the United States and Wall Street (cf. [30]: p. 355f). The Federal Reserve System is a privately 
owned central bank, although the Board of the Federal Reserve is a government institution. The shareholders of the dominant Federal Reserve Bank of New York are the biggest Wall Street banks ([19]: p. 143; [26]: pp. 54-55; [31]: p. 62).

A third possible explanation of the deregulation of the banking sector in the $90 \mathrm{~s}$ is the failure of mainstream economics. The main criticism focuses on the assumption of perfect competitive markets with rational expectations in orthodox economics ([28]: pp. 195-197; [32]: pp. 3-4; cf. [33]). For example, Michel Chossudovsky ([26]: p. 16) points out that Wall Street banks have, contrary to the idea of perfect competition, the ability to manipulate market prices (especially those Wall Street banks which receive inside knowledge from the Federal Reserve Bank of New York). Joseph E. Stiglitz ([19]: pp. 12-13) on the other hand referred to the agency problem-the short-term interests of the managers of modern financial institutions are not compatible with the long-term interests of the shareholders-as a cause of market failure. The agency problem became more severe in the 1980s and 1990s as a result of the transformation of private Wall Street banks from partnerships to public companies ([28]: p. 134).

The neglect of inside knowledge, agency problems and other issues led mainstream economists to believe that markets can solve their problems without government interference in form of regulations. Therefore economic advisors promoted the deregulation of financial markets. However, whatever the main cause of deregulation was-lobbyism, institutional interconnections, or mainstream economics-, the result was that bankers received unlimited freedom to increase profits. Another aspect of deregulation is that immoral behaviour cannot be punished anymore as a crime. A crime is per definition a violation of a rule (or regulation). But deregulation abolishes all rules. Therefore, immoral Wall Street bankers can never become criminals. I am sure that the pickpocket also dreams of the deregulation of property rights.

The invention of CDS was ingenious, because it allowed the private banks to reduce the reserves for risky assets. However, the problem was that a large part of the additional profits had to be paid as insurance fee to the firms that sold the CDS. In order to avoid those losses, the main Wall Street banks started to sell CDSs to themselves. They created special purpose vehicles (SPV), which sold CDSs for the safer loans in order to cover their own assets ([5]: p. 96; [20]; [21]: pp. 67-69; [23]: p. 134; [27]: p. 48). Of course, for the loans that were judged by the banks as unsafe, they still purchased CDSs from other firms. The important question is now, whether the insurance that somebody gives him-/herself really reduces the risk or is it just camouflage. In the case of default the banks would still have to cover for their own loss. Obviously, the only reason for the creation of SPVs was to effectively circumventing the international requirements for capital and reserves [20]. It is therefore not a surprise that the SPVs were the first victims of the economic crisis and by "the end of 2008, the SPV market was essentially closed and almost all of the vehicles had been liquidated or taken over" ([27]: p. 46). 
The logical next step in increasing the profits of the private banks was to get the risky loans off the balance sheet entirely ([23]: p. 43). A CDS successfully reduces the amount of money required as reserves, but it does not eliminate the requirement to maintain reserves [20]. In order to solve this problem the banks started to sell their loans to investors for a fee. But since individual loans are not very market friendly, the banks bundled different loans into so called collateral debt obligations (CDO). The CDOs could then be classified dependent on the probability that a large amount of individual loans in the bundle would default. The CDOs were designed in a way that the safer ones produced lower returns with a high probability, whereas the riskier ones produced higher returns with a low probability. An important side effect of this innovation was that private banks did not need to worry anymore about the quality of the loans, since they would pass the risk off to the investors. This made private banks much more willing to lend to the US subprime market ([5]: p. 89).

As long as the mortgage-default rate in the housing boom was extremely low-owing to rising home prices even subprime-mortgage holders could get their money back-, aggressive investors could make an enormous profit by buying risky CDOs ([29]: p. 107ff; [34]: p. 89). The risky CDOs were so profitable that they created a huge demand for subprime mortgages, which again fuelled the housing boom ([34]: p. 90). This created an enormous unregulated shadow banking system, which at the peak accumulated more assets than the regulated deposit-taking banks ([35]: p. 13). The result was that it became much more profitable for the private banks to create and trade CDOs than it was to give loans to the real economy [36]. Considering that one of the main functions of the banking sector was to allocate resources in the economy efficiently, the new financial innovations created an incentive system that became a distraction from their main purpose ([19]: pp. 6-7).

But even CDSs, SPVs, and CDOs as strategies to circumvent the regulations did not produce enough profits for the private banks. Some bankers started to sell extremely toxic loans bundled into CDOs for high fees and bet on them (by buying an insurance in the form of a CDS) that the borrowers will default. And of course, they could be quite certain that this event would occur, because they created those worthless CDOs [20]. This strategy became possible, because CDSs were entirely unregulated. In contrast to normal insurance to hold the insured asset or suffer any loss was not a requirement for setting up a CDS, and therefore it became a tool of speculation ([23]: p. 50; [25]: p. 368; cf. [35]: p. 12). This speculative use of CDSs made fraud more attractive ([25]: p. 368; [37]; [38]). If, for example, I were allowed to buy a fire insurance for my neighbour's house, I would suddenly have a strong incentive to torch it ([29]: p. 171; [34]: p. 103; cf. [39]). The same logic applies to the bankers too. If the bankers were betting that their own CDOs would default, then they had a strong incentive to make sure that they did. In this way they could cash in twice. They first got the fees for the CDOs from the investor and later the money for the CDSs from the insurance 
company ([23]: pp. 143-145; [39]; [40]: p. 91). "As a result, the losses from the housing collapse were multiplied exponentially" ([23]: p. 145). In other words, not only did the profits of the private banks involved skyrocket, but also the risk for the whole society (or better the whole global economy). Goldman Sachs, Merrill Lynch, the securities arm of Citigroup, Deutsche Bank, and UBS were the major participants in this kind of derivatives business ([23]: p. 131).

However, one important question remains. Why did the investors buy worthless CDOs from the big Wall Street banks? Weren't they careless, and was it not therefore their own fault? The answer is that the investors had no access to the information available to the major private banks, and that they therefore had to rely on the assessments of the rating agencies ([23]: p. xxv, 119; cf. [32]: pp. $130-131,155)$. But what most of the customers of the major private banks did not know was that the rating agencies were not disinterested parties ([19]: p. 92; [24]: pp. 112-113; [40]: p. 84). These agencies were paid between US $\$ 500,000$ and US $\$ 850,000$ for the assessment of each CDO by the private banks ([23]: p. 146; cf. [29]: p. 109). Therefore, they "had an incentive to please those who were paying them" ([19]: p. 92). Otherwise they would have lost the private banks as their customers to another more cooperative rating agency (cf. [18]: p. 267). As a result, the rating agencies "colluded and connived" with the private banks ([20]; cf. [29]: p. 109; [41]: pp. 86-87). And these agencies were very well protected from angry investors, who might have sued the rating agencies for publishing misleading information. American courts ruled that the ratings were merely journalistic opinions, which are protected by the First Amendment of the U.S. constitution ([23]: p. 120), “despite the central role given to ratings in many types of regulations, including bank capital adequacy and Federal Reserve collateralized lending facilities" ([32]: p. 281).

\subsection{The Lehman Brothers Crash, Bailouts, and Quantitative Easing}

Unfortunately for the major Wall Street banks this heavenly condition did not last forever. The private bankers did not (want to) realize that their ingenious mathematical formulas to calculate risk would only work as long as not a large number of people would default at the same time [42]. But in summer of 2008 AIG started to get into trouble, because the number of defaults was increasing, and the private banks demanded that AIG cover the cash collateral for their "insurances" (the CDSs). Goldman Sachs alone received US \$5.9 billion in collateral from AIG in the months before the collapse of this insurance company. Those large amounts of money transfers finally led to a liquidity crisis of AIG with the threat of an imminent bankruptcy [39]. The U.S. Federal Reserve stepped in and bailed it out with altogether US $\$ 182.5$ billion [43], because just one day after the collapse of Lehman Brothers, the Fed was "very concerned about a number of other major firms that were under intense stress" and "the risks to the financial system as a whole" [44]. In other words, the major Wall Street banks were saved 
with taxpayers' money, in contrast to the standard procedure in which the banks' shareholders would have lost their money and the executives of the bank would have lost their jobs ([19]: p. 121). Interestingly, the following stream of bailouts and programs of the Fed to buy up the toxic assets "at or close to the original price" [45] — which re-inflated the bubble [39] — was quickly transferred into new opportunities for the major private banks to increase their profits further by plundering the state (cf. [46]). With the guarantee of the Fed that the big Wall Street banks would get bailed out whenever necessary, they could be even more reckless in taking risks, because the taxpayer would cover for them ([32]: p. 277; [35], pp. 21, 61; [39]).

Additionally, the major private banks could borrow money from the Fed at zero percent interest rates. The investment banks Goldman Sachs and Morgan Stanley were overnight approved - the law required a five-day waiting periodto become traditional bank holding companies, which allowed them to borrow money from the Federal Reserve at these low interest rates [39]. The government provided the money to the big Wall Street banks for free-borrowing money at zero percent interest rates "is a huge gift, but one hidden from the taxpayers" ([19]: p. 110) - , because it wanted them to lend money to the real economy in order to restart the recovery (cf. [40]: p. 26), although they did not impose any serious restrictions on how the banks could use the money ([40], p. 27; cf. [47]: p. 5). But the major private banks preferred to use the money in a different way. One common strategy was to borrow the money from the government for nothing and to lend it back to the government for a reasonable interest rate of three to four percent ([39]; [47]: pp. 31-33). In this way, they could create a steady stream of income at no costs and without any risks. As a result the governments financed their own indebtedness ([26]: pp. 54-55) in order to achieve a massive redistribution of wealth from the taxpayers to the private banks ([19]: p. 122). At least in Europe the national governments demanded banks' stocks in return of the bailout, whereas in the United States it was a free giveaway ([19]: p. 22; [25]: pp: 372-373). However, the European bailout of Greece was in fact a bailout of Greece's creditors in the sense of a free giveaway [48]. Already in 2009 the IMF predicted accurately that the governments' direct support for the private banks, the stimulus packages for the real economy and the decrease of tax revenues would lead to a deterioration of public finances ([49]: p. 1) and finally to an "entitlement reform" ([49]: p. 32), which is of course nothing else than austerity programs ([28]: p. 43).

The most important conclusion from this story is that private banks and society as a whole have a fundamental conflict of interest. The private banks by practicing fractional reserve banking have an interest in increasing the risk in order to increase their profits. Society as a whole on the other hand has a strong interest in limiting the risks created by the private banks. Those risks are not only bad for the depositors of the private banks, but for everybody else, because bankruptcies of private banks can easily lead to major economic crises which can destroy 
large sections of the economy (cf. [36]) and put pressure on public finances.

\section{The Failure of the Conventional Solutions to Address the Problem}

How can societies protect themselves against depressions that are caused by the greed of the bankers? The most obvious solution is to reduce the risk by reintroducing tough regulations. The increase of the capitalization of private banks could be a start ([27]: p. 40; [50]). If private banks had more of their own capital than they would be better prepared for a situation in which their debtors default. Unfortunately, an increase of the capital buffers alone will not solve the problem, unless the loophole of the unregulated over-the-counter market is fixed ([26]: p. 58; [32]: p. 297; [35]: p. iii, xiv; [47]: p. 207). This refers mainly to the excessive speculation on the CDSs market, which allowed the private banks to leverage way beyond the regulatory limits. The problem is however that some derivatives are regarded as a "useful tool for risk management" and should not be prohibited ([16]: p. 144; [19]: p. 174). Therefore it was proposed to establish a Financial Products Safety Commission, which should decide whether a derivative is useful or harmful for society ([33]; [35]: p. 12, 21; [34]: pp. 163-164). Another proposal aims to introduce a "collective insurance policy" against a financial meltdown caused by a burst of a bubble ([34]: p. 156). Similar to a Tobin tax-which demanded a one percent tax on currency transfers worldwide-such a tax on financial transactions would not only make speculations less attractive, but could also be used "to fund prop up the real economy that will, sooner or later, suffer [...] from collapsing financial markets" ([34]: pp. 158-159; cf. [16]: p. 271; [19]: p. 131).

Another proposal is to punish private banks much more severely for their wrongdoings. This could be done by confiscating "those assets which were obtained through fraud and financial manipulation" ([26]: p. 58) and by sentencing more top managers to jail time ([32]: p. 297; [51]). Furthermore, it could be argued that the government has a responsibility to stop the private banks from becoming "too-big-to-fail, too-big-to-be-resolved, and too-intertwined-to-be-resolved" ([19]: p. 168), which would require a stricter control of takeovers and fusions. A reduction of the connectedness of the financial markets could also limit the impact of financial meltdowns ([32]: p. 297). And finally, an abolishment of the rating agencies' First Amendment exemption from lawsuits could limit the cases of fraud (cf. [32]: p. 281), because rating agencies would be forced to balance the interest of the Wall Street banks (which pay them) and the interests of the investors (which could sue them).

All of the above proposals to limit the risk-taking behaviour of private banks-the shadow banking system would not be touched by those regulations-have something in common. Although they appear to be quite radical, they are not. These proposals keep the current financial system intact and just add regulations that should limit the worst pathologies. Some of the proposals 
are even self-evident. It goes without saying that a top manager of a Wall Street bank should be punished according to his/her crimes as everybody else. However, none of these proposals tries to change the fundamental conflict of interest between private banks and society at large. And if this fundamental interest conflict cannot be overcome, the private banks would still have a strong incentive to search for loopholes in the regulations and to exploit the freedom that the regulations give them ([34]: p. 155; cf. [40]: pp. 231-232). John Kay "argues that it is folly to try to control or eliminate the casino since the industry will always invent new ways to work around regulations" ([34]: p. 29).

Furthermore, it would become necessary to introduce those regulations worldwide, otherwise capital would move to the less regulated markets ([34]: p. 71). Competition between different countries to receive as much of this capital as possible could result in a race to the bottom in financial regulation ([35]: p. 17). Therefore, it is argued that the establishment of powerful global institutions like a global financial regulatory system or even a global central bank with a global currency would be necessary. Without a global financial regulatory system that introduces regulations for a global financial market "a new era of instability" and “economic weakness" could be expected ([19]: p. 235; [21]: pp. 209-210; [35]: p. 41; [52]: p. 93). This proposal is connected to a replacement of the U.S. dollar by a new global currency ([19]: p. 231; [35]: p. 48). Some plans regard the Special Drawing Rights of the IMF as a good candidate for such a new global currency ([35]: p. iv; [53]: p. 343). The logical next step would be the establishment of a global central bank, which would be in charge of the global currency. The idea of a global central bank is not new. Already in 1998 Jeffrey Garten, Undersecretary of Commerce for International Trade in the Clinton administration, who served also in various positions in the Nixon, Ford, and Carter administrations and was a former Managing Director at Lehman Brothers, proposed the creation of a “Global Fed" ([53]: p. 348).

The problem of these proposals is that it is not clear how those global institutions could be legitimized democratically (cf. [16]: p. 210). Neither the United Nations nor the International Monetary Fund or the World Bank is legitimized through democratic elections. Not only have the United States and Europe (as well as Japan) more power in those organizations than the developing countries, but also several of the countries in those organizations have no democratically elected governments. This creates the fear that more and more decisions are transferred from democratically legitimized national parliaments to global institutions, which are not anymore under the control of the people ([54]: p. 289). The lack of democratic control is a serious problem, because we can expect an "interconnected group of international elites" (including the major Wall Street bankers) to be in charge ([53]: pp. 350-351). But in this case it is not reasonable to expect a global financial regulatory system or a global central bank to introduce tough regulations that would limit the private banks' ability to take risks. It is not very smart to put the fox in charge of the henhouse. 


\section{Conclusions}

It seems that all the conventional proposals have not and will not solve the problem. The many reforms of financial markets in the years after Lehman Brothers did not prevent the rise of the notional amount of outstanding contracts at the over-the-counter derivatives markets to US $\$ 710$ trillion-a new record high —at the end of 2013 ([55]: p. 1). And although the OTC market of CDSs decreased from US \$58 trillion at end-2007 to US \$21 trillion at end-2013 ([55]: p. 5), other lucrative derivatives markets expanded. Furthermore, if Goldman Sachs Bank USA with total assets of US \$0.1 trillion had at the end of 2013 a total exposure to derivatives of US $\$ 48.6$ trillion ([56]: Table 1), then it is clear that very little has changed. Representatives of the private banks even warned politicians at the February G20-meeting in Sydney that any further regulations could lead to a financial crisis [57]. However, two things have changed. First, the too-big-to-fail banks are bigger than ever before, and therefore also the systemic risk spreading from these banks has increased. And second, the real world economy has still not recovered from the Lehman Brothers shock. Not only have the emerging market economies still problems to adjust "to weaker-than-expected medium-term growth prospects" (that means pre-2007 growth rates) but also advanced economies "still face risks of stagnation" ([58]: p. 16), which could adversely affect the growth potential, "because of lower investment, including in research and development and because of lower labour supply as a result of hysteresis in unemployment-the rise in structural unemployment from prolonged cyclical unemployment" ([58]: p. 17).

The efforts of financial regulators and central banks failed, because they did not address the fundamental problem - the ability of private banks to create an unlimited amount of money in order to increase their profits ([59]: p. 8). If we want to protect the real economy and our societies from the risks the private bankers are willing to take, then it is necessary to deny the private banks the ability to create money through loans. In the second part [60] of this series I will discuss three more radical proposals with the aim to formulate a synthesis of those approaches.

\section{Conflicts of Interest}

The authors declare no conflicts of interest regarding the publication of this paper.

\section{References}

[1] Mankiw, N.G. (2007) Essentials of Economics. 4th Edition, Thomson, Mason.

[2] Mishkin, F.S. (2016) The Economics of Money, Banking, and Financial Markets. 11th Edition, Pearson, Harlow.

[3] Matthews, K. and Thompson, J. (2014) The Economics of Banking. 3rd Edition, Wiley, Chichester.

[4] Korten, D.C. (2001) When Corporations Rule the World. 2nd Edition, Berrett-Koehler, San Francisco. 
[5] Jackson, A. and Dyson, B. (2012) Modernising Money. Positive Money, London.

[6] Sigurjónsson, F. (2015) Monetary Reform: A Better Monetary System for Iceland. Report Commissioned by the Prime Minister of Iceland.

[7] Rochon, L.-P. (1999) Credit, Money and Production. Edward Elgar, Cheltenham and Northampton.

[8] Kaldor, N. (1985) How Monetarism Failed. Challenge, 28, 4-13. https://doi.org/10.1080/05775132.01.11470996

[9] Moore, B.J. (1988) Horizontalists and Verticalists. Cambridge University Press, Cambridge.

[10] Goodhart, C.A.E. (1994) What Should Central Banks Do? Economic Journal, 104, 1424-1436. https://doi.org/10.2307/2235461

[11] Federal Reserve Bank of Chicago (1994) Modern Money Mechanics. Federal Reserve Bank of Chicago, Chicago.

[12] Deutsche Bundesbank (1995) Die Geldpolitik der Bundesbank. Deutsche Bundesbank, Frankfurt.

[13] McLeay, M., Radia, A. and Thomas, R. (2014) Money Creation in the Modern Economy. Bank of England Quarterly Bulletin, Q1, 14-27.

[14] Rowbotham, M. (1998) The Grip of Death. Jon Carpenter, Charlbury.

[15] Benes, J. and Kumhof, M. (2012) The Chicago Plan Revisited. IMF Working Paper No. $12 / 202$.

[16] King, M. (2016) The End of Alchemy. Little Brown, London.

[17] Whitney, M. (2010) Securitization. In: Chossudovsky, M. and Marshall, A.G., Eds., The Global Economic Crisis, Global Research, Montreal, 375-380.

[18] Calomiris, C.W. and Haber, S.H. (2014) Fragile by Design. Princeton University Press, Princeton.

[19] Stiglitz, J.E. (2010) Freefall. Norton, New York.

[20] Chang, M. (2010) Financial Fraud and the Global Derivative Casino. http://www.globalresearch.ca/index.php?context=va\&aid=21245

[21] Münchau, W. (2010) The Meltdown Years. McGraw Hill, New York.

[22] Das, S. (2009) Credit Default Swaps. http://www.globalresearch.ca/index.php?context=va\&aid=13157

[23] Financial Crisis Inquiry Commission (2011) The Financial Crisis Inquiry Report. Public Affairs, New York.

[24] McLean, B. and Nocera, J. (2010) All the Devils Are Here. Portfolio, New York.

[25] Brown, E. (2010) Wall Street's Ponzi Scheme. In: Chossudovsky, M. and Marshall, A.G., Eds., The Global Economic Crisis, Global Research, Montreal, 367-374.

[26] Chossudovsky, M. (2010) The Global Economic Crisis. In: Chossudovsky, M. and Marshall, A.G., Eds., The Global Economic Crisis, Global Research, Montreal, 3-60.

[27] Davies, H. (2010) The Financial Crisis: Who Is To Blame? Polity, Cambridge.

[28] Wolf, M. (2014) The Shifts and the Shocks. Penguin Books, London.

[29] McDonald, L. (2009) A Colossal Failure of Common Sense. Ebury Press, London.

[30] Cook, R.C. (2010) The Democratization of the Monetary System. In: Chossudovsky, M. and Marshall, A.G., Eds., The Global Economic Crisis, Global Research, Montreal, 355-363.

[31] Hsu, T.C. (2010) Death of the American Empire. In: Chossudovsky, M. and Mar- 
shall, A.G., Eds., The Global Economic Crisis, Global Research, Montreal, 61-71.

[32] Smith, Y. (2010). Econned. Palgrave Macmillan, New York.

[33] Stiglitz, J.E. (2008) Capitalist Fools. http://www.globalresearch.ca/index.php?context=va\&aid=11356

[34] Leopold, L. (2009) The Looting of America. Chelsea Green, White River Junction.

[35] United Nations Conference on Trade and Development (2009) The Global Economic Crisis. United Nations, New York.

[36] Salbuchi, A. (2011) The Money Masters. http://www.globalresearch.ca/index.php?context=va\&aid=26775

[37] Toussaint, E. (2011) Financial Destabilization, Credit Default Swaps (CDS) and the Rating Agencies. http://www.globalresearch.ca/index.php?context=va\&aid=26757

[38] Lendman, S. (2012) Goldman Sachs. http://www.globalresearch.ca/index.php?context=va\&aid=29823

[39] Taibbi, M. (2010) Wall Street's Bailout Hustle. http://www.globalresearch.ca/index.php?context=va\&aid=17848

[40] Barofsky, N. (2012) Bailout. Free Press, New York.

[41] Taibbi, M. (2011) Griftopia. Spiegel \& Grau, New York.

[42] Salmon, F. (2009) Recipe for Disaster. http://www.globalresearch.ca/index.php?context=va\&aid=12447

[43] Son, H. (2009) AIG’s Trustees Shun “Shadow Board”, Seek Directors (Update2). (The article is not anymore available online)

[44] Bernake, B.S. (2009) Testimony. http://www.federalreserve.gov/newsevents/testimony/bernanke20090324a.htm

[45] Chang, M. (2013) Shadow Banking and Financial Fraud. http://www.globalresearch.ca/shadow-banking-and-financial-fraud-massive-asset-i nflation-who-really-benefits/5337533 (The article is not anymore available online)

[46] Whitney, M. (2010) More Toxic Paper. http://www.globalresearch.ca/index.php?context=va\&aid=18475

[47] Prins, N. (2009) It Takes a Pillage. Wiley, Hoboken.

[48] Meck, G. (2011) Schuldenkrise. http://www.faz.net/-gqe-6u72c

[49] International Monetary Fund (2009) Fiscal Implications of the Global Economic and Financial Crisis. IMF, Washington DC.

[50] Hau, H. and Lucke, B. (2011) Zwangs-Rekapitalisierunggefährdeter Banken. http://www.faz.net/-027a0s

[51] Theurer, M. (2013) Großbritannien: "RücksichtslosesFehlverhalten” von Bankernsollstrafbarwerden. http://www.faz.net/-gqg-7b3s3

[52] Derviş, K. (2009) Interdependence, Global Issues Management, and Global Economic Governance. In: Burns, N. and Price, J., Eds., The Global Economic Crisis, The Aspen Institute, Washington DC, 93-103.

[53] Marshall, A.G. (2010) The Financial New World Order. In: Chossudovsky, M. and Marshall, A.G., Eds., The Global Economic Crisis, Global Research, Montreal, 343-354.

[54] Marshall, A.G. (2010) The Political Economy of World Government. In: Chossudovsky, M. and Marshall, A.G., Eds., The Global Economic Crisis, Global Research, Montreal, 262-299. 
[55] Bank for International Settlements (2014) Statistical Release: OTC Derivatives Statistics at End-December 2013. http://www.bis.org/publ/otc_hy1405.pdf

[56] Office of the Comptroller of the Currency (2014) OCC's Quaterly Report on Bank Trading and Derivatives Activities Fourth Quarter 2013.

http://www.occ.gov/topics/capital-markets/financial-markets/trading/derivatives/d q413.pdf

[57] Hein, C. (2014) G20-Gipfel in Sydney. http://www.faz.net/-gqg-7mobj

[58] International Monetary Fund (2014) World Economic Outlook. https://www.imf.org/external/pubs/ft/weo/2014/01/pdf/text.pdf

[59] Turner, A. (2015) Foreword. In: Sigurjónsson, F., Ed., Monetary Reform: A Better Monetary System for Iceland, Report Commissioned by the Prime Minister of Iceland, 8.

[60] Etzrodt, C. (in press) Modern Sovereign Money Part II, A Synthesis of the Chicago Plan, Sovereign Money, and the Modern Money Theory. Open Journal of Social Sciences. 